une revue Gallia

Rhône-Alpes | 2008

\title{
Cruas
}

place des Martyrs

\section{Christine Ronco}

\section{(2) OpenEdition \\ 1 Journals}

Édition électronique

URL : http://journals.openedition.org/adlfi/1792

ISSN : 2114-0502

Éditeur

Ministère de la culture

Référence électronique

Christine Ronco, «Cruas », ADLFI. Archéologie de la France - Informations [En ligne], Rhône-Alpes, mis en ligne le 01 mars 2008, consulté le 20 avril 2019. URL : http://journals.openedition.org/adlfi/1792

Ce document a été généré automatiquement le 20 avril 2019.

(c) Ministère de la Culture et de la Communication, CNRS 


\section{Cruas}

place des Martyrs

\section{Christine Ronco}

Identifiant de l'opération archéologique : 9891

Date de l'opération : 2008 (EX)

1 L'opération de diagnostic réalisée dans le jardin de la cure, place des Martyrs, n'a pas révélé de niveaux archéologiques. Seule une partie du mur occidental du jardin, constitué de moellons en moyen appareil de calcaire local, semble appartenir au cloître daté du Xle s.

Christine Ronco

INDEX

Thèmes : cloître, mur

Index géographique : Rhône-Alpes, Ardèche (07), Cruas

operation Expertise (EX)

Index chronologique : Xe siècle apr. J.-C.

\section{AUTEUR}

CHRISTINE RONCO

Inrap 